\title{
ONDERZOEKSNOTITIES
}

\section{Geëiste en opgelegde sancties bij de strafrechtelijke afhandeling van georganiseerde criminaliteit $^{*}$}

\author{
Karin van Wingerde \& Henk van de Bunt
}

De aanpak van georganiseerde criminaliteit heeft de afgelopen jaren topprioriteit gekregen. De vraag is of de geleverde inspanningen ook in strafrechtelijke zin in resultaat worden omgezet. In deze bijdrage worden de resultaten beschreven van een verkennende en descriptieve studie naar de discrepanties tussen strafeis en vonnis in georganiseerde-misdaadzaken. Startpunt voor deze analyse zijn 70 zaken uit de Monitor Georganiseerde Criminaliteit. Dit onderzoek laat zien dat de door de rechter opgelegde vrijheidsstraffen in eerste aanleg en in hoger beroep in meer dan 80 procent van de gevallen afwijken van de eis van de officier van justitie. In driekwart van de gevallen legt de rechter bovendien een lagere straf op dan door de officier van justitie was geëist. Deze verschillen wijken af van de in de literatuur beschreven consensus tussen strafeis en strafmaat bij minder ernstige en veelvoorkomende vormen van criminaliteit.

\section{Inleiding}

Regelmatig verschijnen er berichten in de media over de opsporing van omvangrijke strafbare feiten gepleegd door criminele samenwerkingsverbanden. Er worden beelden getoond van personen 'uit het criminele circuit' die op klaarlichte dag geliquideerd zijn en van rechercheurs in witte pakken die zorgvuldig sporen veiligstellen. Ook wordt er met een zekere regelmaat door de douane of de politie informatie verstrekt over grote drugsvangsten en over de ontmanteling van hennepkwekerijen.

De vraag is echter of de getoonde daadkracht in strafrechtelijke zin ook in resultaat wordt omgezet. Deze vraag kan slechts met veel moeite worden beantwoord. Het Openbaar Ministerie (OM) en het ministerie van Veiligheid en Justitie houden geen gegevens bij over het verloop van de strafrechtelijke afdoening van dergelijke zaken. Bij gebrek aan systematisch verzamelde gegevens kunnen incidentele, geruchtmakende zaken het beeld over de stand van zaken gaan bepalen.

Uit onderzoek van Kort e.a. (2014) blijkt dat er in het algemeen veel onvrede bestaat bij politiemensen over het strafrechtelijk vervolg op hun opsporingswerk. Politiefunctionarissen hebben weinig vertrouwen in de rechterlijke macht. Soms wordt jarenlang recherchewerk met een enkele pennenstreek van de rechter

* Met dank aan Daphne Postma en Mandy Maaskant, beiden onderzoekers aan de Erasmus Universiteit Rotterdam, voor het verzamelen van de data. 
tenietgedaan, althans in de ogen van de politiefunctionarissen (Kort \& Terpstra, 2015a; 2015b). Dit is bijvoorbeeld het geval bij onverwachte vrijspraken of bij rechterlijke uitspraken die sterk afwijken van de eisen van de officier van justitie. Ook het OM laat zichzelf niet onbetuigd in het uiten van kritiek op de rechter. Zo verweet een officier, gespecialiseerd in de bestrijding van mensenhandel, in een interview in NRC Handelsblad enkele rechters onvoldoende kennis in huis te hebben van de problematiek van mensenhandel (Jorritsma \& Van Steenbergen, 2014).

Klopt dit beeld wel van strafrechters die in grote zaken ten opzichte van de eis van de officier van justitie (veel) milder vonnissen? In deze bijdrage richten wij ons op de strafrechtelijke afhandeling van georganiseerde criminaliteit. Wij beantwoorden drie vragen:

- In hoeverre komen discrepanties voor tussen strafeis en vonnis, in eerste aanleg en in hoger beroep?

- In hoeverre komen discrepanties voor tussen eerste aanleg en hoger beroep?

- Hoe verschillen eis en vonnis in eerste en tweede aanleg van elkaar zowel qua richting (hoger of lager) als qua duur van de vrijheidsstraf?

Deze vragen worden beantwoord op basis van de eerste resultaten uit een lopend onderzoek naar de strafrechtelijke afdoening van georganiseerde criminaliteit. In deze verkennende en descriptieve bijdrage gaan wij uitsluitend in op de discrepanties tussen strafeis en opgelegde sancties, in eerste aanleg en in hoger beroep. Wij laten de cassatie en de executie buiten beschouwing. Ook gaan wij niet in op andere beslissingen in de strafrechtsketen, zoals de beslissing om een georganiseerde-misdaadzaak al dan niet in behandeling te nemen en adviezen inzake gratieverlening, ook al geven deze beslissingen mede vorm aan de keuzes die binnen het strafrechtelijk systeem worden gemaakt. Tot slot beperken wij ons in deze bijdrage tot vrijheidsstraffen.

In deze bijdrage gaan we eerst in op eerder onderzoek naar de relatie tussen strafeis en vonnis. Daarna volgt een bespreking van de voor dit onderzoek beschikbare gegevens. Vervolgens presenteren wij de resultaten en gaan we achtereenvolgens in op de discrepanties tussen eis en vonnis in eerste aanleg en in hoger beroep en de verschillen tussen de in eerste aanleg en in hoger beroep opgelegde sancties. In de conclusie wordt stilgestaan bij de beperkingen van de gebruikte gegevens en de betekenis van de resultaten.

\section{Eerder onderzoek naar discrepanties tussen eis en vonnis.}

De verschillende bevoegdheden van officieren van justitie en rechters in de berechting van strafzaken zijn in de wet duidelijk omschreven: de officier vordert, de rechter beslist over het bewijs en de sanctie. In de praktijk is de rolverdeling niet zo dichotoom. De officier van justitie is weliswaar procespartij, maar van deze functionaris wordt wel een 'magistratelijke' houding verwacht (Van de Bunt \& Van Gelder, 2012). De 'onafhankelijke' rechter is in verschillende opzichten afhankelijk van de keuzes die door de officier zijn gemaakt. Zo kan de rechter zich 
bijvoorbeeld niet uitspreken over feiten die niet door de officier van justitie zijn tenlastegelegd en hij beslist derhalve binnen de marges die door de officier zijn vastgesteld. Beide partijen kunnen het zich niet permitteren om steeds weer opnieuw van mening te verschillen. Om de afhandeling van zaken efficiënt te kunnen laten verlopen, is het noodzakelijk dat er een bepaalde mate van working consensus (Van de Bunt, 1992) bestaat tussen beide partijen over bijvoorbeeld routinekwesties, zoals de strafmaat bij rijden onder invloed, of over de strafwaardigheid van 'nieuwe' misdrijven, zoals mensensmokkel of cybercrimes. Deze werkovereenstemming kan bestaan uit impliciete gedeelde opvattingen, maar wordt tegenwoordig ook steeds vaker geëxpliciteerd in richtlijnen, procedures en vaste boetebedragen voor veelvoorkomende delicten, zowel binnen het $\mathrm{OM}$ als binnen de rechterlijke macht (Boone \& Korf, 2010; Van de Bunt \& Van Gelder, 2012). De besluitvorming inzake vervolging en bestraffing van minder ernstige, maar veelvoorkomende misdrijven is tegenwoordig dus sterk gestandaardiseerd.

In de praktijk blijkt het dan ook wel mee te vallen met het bestaan van discrepanties tussen eisen en vonnissen. Uit het jaarlijks gepubliceerde overzicht naar de ontwikkelingen in criminaliteit en rechtshandhaving in Nederland blijkt dat de rechter in 88 procent van de zaken conform de eis van het OM tot een schuldigverklaring besluit. Slechts ongeveer 11 procent van de zaken resulteert in vrijspraak of ontslag van rechtsvervolging (Verkleij \& Meijer, 2015, 39-40). In een groot deel van de gevallen volgt de rechter bovendien de eis voor wat betreft de aard van de op te leggen sanctie. Deze percentages zijn ook al jaren hoog en schommelen sinds eind jaren zeventig tussen de 85 en 100 procent (Van der Werff, 1978; Van der Werff \& Van der Zee-Nefkens, 1978; Slotboom e.a., 1992; Lodewijks e.a., 2010; Bosmans \& Pemberton, 2012). Zo onderzochten Slotboom en collega's (1992) de relatie tussen strafeis en vonnis in misdrijfzaken die in 1991 door vier parketten werden afgedaan. De auteurs lieten zien dat in 97 procent van de gevallen overeenkomstig de eis van het OM tot een schuldigverklaring, vrijspraak of ontslag van rechtsvervolging werd besloten (p. 63). In 56 procent van de zaken volgde de rechter de strafeis naar aard en hoogte precies (p. 64).

Geldt dit ook voor de zwaardere zaken? Naar de verhouding tussen strafeis en vonnis in de afdoening van georganiseerde criminaliteit is in ons land - voor zover ons bekend - niet eerder onderzoek gedaan. Ook in de internationale literatuur wordt niet of nauwelijks aandacht besteed aan de bestraffing van georganiseerde criminaliteit noch aan discrepanties tussen strafeis en vonnis. De internationale literatuur richt zich vooral op het fenomeen (Paoli, 2014) en - als het gaat over de aanpak - op verschillen in wet- en regelgeving of handhavingsbeleid (Desroches, 2013; Campbell, 2013) en op preventiestrategieën (Paoli, 2014). Voor zover er inzicht bestaat in de bestraffing van georganiseerde criminaliteit, beperkt dit zich meestal tot geaggregeerde gegevens over aantallen aangepakte criminele samenwerkingsverbanden, aantallen afgedane zaken of gegevens over het gemiddeld aantal jaar detentie dat is opgelegd of het bedrag dat aan wederrechtelijk verkregen vermogen is ontnomen (Albanese, 2011).

Naar de discrepanties in de strafrechtelijke afdoening van andere vormen van zware criminaliteit is eveneens betrekkelijk weinig onderzoek gedaan. Een uitzon- 
dering is het onderzoek van Zoomer (1981) naar de verschillen tussen geëiste en opgelegde straffen in gevallen van zware criminaliteit tussen 1973 en 1976. Uit dit onderzoek kwam naar voren dat de rechter vaker niet dan wel conform de eis van de officier van justitie straft. Nieuwbeerta en Van Wingerden (2006) onderzochten hoe moord en doodslag werden vervolgd en berecht tussen 1993 en 2004. In 65 procent van de door hen bestudeerde gevallen werd door de rechter een lagere straf opgelegd dan door het OM was geëist. In 28 procent van de gevallen strafte de rechter gelijk aan de eis van het OM en in 7 procent van de gevallen werd een hogere vrijheidsstraf opgelegd dan geëist. De mate waarin de rechter afweek van de eis bleek echter beperkt. De gemiddelde opgelegde strafduur was destijds 7,6 jaar, de gemiddelde eis 8,8 jaar (p. 283).

Onze verwachting is dat de kans op discrepanties tussen eis en vonnis bij de behandeling van georganiseerde criminaliteit groter is dan bij de routinemisdrijven. Het is immers aannemelijk dat er juist beoordelingsverschillen optreden in misdrijfzaken rond grote, ernstige vormen van criminaliteit, zoals mensenhandel en andere vormen van georganiseerde criminaliteit. Het gaat veelal om complexe zaken waarbij het bewijs voor meerdere interpretaties vatbaar is (Ministerie van Veiligheid en Justitie, 2008; Boerman e.a., 2012; Nieuwenhuis \& Pannekoek, 2012; Nationaal Rapporteur Mensenhandel, 2012). Naarmate het bewijs moeilijker is vast te stellen of te duiden, neemt ook de kans op beoordelingsverschillen toe en neemt het aantal zaken af waarin de dader door de rechter schuldig wordt verklaard (Brouwers \& Eggen, 2013, 136). Zo bleek uit een analyse van mensenhandelzaken door de Nationaal Rapporteur Mensenhandel (2012) dat de rechter in 85 procent van de geanalyseerde gevallen tot een lagere straf kwam dan geëist (p. 111). Uit de vierde rapportage van de Monitor Georganiseerde Criminaliteit werd duidelijk dat er in ontnemingsvorderingen een aanzienlijk verschil bestaat tussen enerzijds het totale bedrag dat door officieren van justitie in eerste aanleg ter ontneming was geëist en de uiteindelijke afdoening door de rechter (Kruisbergen e.a., 2012, 247). Verklaringen hiervoor waren onder meer dat de rechter (1) tot een ander oordeel komt over de ernst van de strafbare feiten, (2) reden ziet om een 'korting' te geven op het te ontnemen bedrag vanwege overschrijding van de redelijke termijn waarbinnen de zaak had moeten plaatsvinden, en (3) de sanctie matigt vanwege de beperkte betalingscapaciteit van de dader (p. 256).

Georganiseerde misdaad behoort tot de meest ernstige vormen van criminaliteit. De aanpak van deze criminaliteit is dan ook een van de belangrijkste prioriteiten van het OM. Over het effect hiervan, in termen van aantallen opgelegde detentiejaren, is weinig bekend, zowel voor wat betreft de berechting in eerste aanleg als de berechting in hoger beroep. De beoordeling van deze effectiviteit wordt dan ook sterk door incidenten bepaald en berust niet op feitelijke kennis. Het doel van dit beschrijvende onderzoek is om te voorzien in deze lacune.

\section{Data en analyse}

Dat er zo weinig onderzoek is gedaan naar de strafrechtelijke afdoening van zwaardere criminaliteit heeft als reden dat data over geëiste en opgelegde sancties 
niet zonder meer beschikbaar zijn (Nieuwbeerta \& Van Wingerden, 2006; Van Wingerden \& Nieuwbeerta, 2010). In de eerste plaats is informatie over de opgelegde sancties op verschillende plekken geregistreerd. Zo is informatie over de afdoening van zaken onder andere opgenomen in het Justitieel Documentatiesysteem (JDS). Gegevens over de executie van sancties worden geregistreerd door het Centraal Justitieel Incassobureau (CJIB) of bij het OM zelf. Daarnaast zijn er ook gegevens nodig over de door de officier van justitie geëiste straffen, bijvoorbeeld in de vorm van requisitoiren of rechterlijke vonnissen. Deze gegevens worden nergens centraal geregistreerd en moeten per geval worden verzameld door ze bij de afzonderlijke parketten op te vragen of te verzamelen via openbare bronnen, zoals Rechtspraak.nl.

Voor al deze databronnen geldt dat de volledigheid afhangt van een correcte wijze van registreren. Registratie- en interpretatieverschillen zorgen er bovendien voor dat de gegevens niet altijd zonder meer aan elkaar kunnen worden gekoppeld en met elkaar worden vergeleken. Analyse van de relatie tussen strafeis en vonnis is derhalve een tijdrovende klus.

In deze bijdrage analyseren wij gegevens over geëiste en opgelegde straffen in strafzaken tegen verdachten van georganiseerde criminaliteit. Voor deze groep verdachten bestaat er echter geen eenduidig steekproefkader. Er bestaat bijvoorbeeld geen centraal overzicht waarin de daders van georganiseerde criminaliteit zijn opgenomen. De casuïstiek voor dit onderzoek hebben wij daarom onttrokken aan de Monitor Georganiseerde Criminaliteit (hierna: de Monitor). De Monitor betreft een doorlopend onderzoeksproject waarin elke vier jaar dossiers van ongeveer 40 grootschalige opsporingsonderzoeken naar georganiseerde criminaliteit worden geanalyseerd (Kleemans e.a., 1998; 2002; Van de Bunt \& Kleemans, 2007; Kruisbergen e.a., 2012). Sinds 1996 zijn er tot nu toe 150 strafzaken bestudeerd. Daarbij gaat het onder andere om drugshandel, mensenhandel en -smokkel en fraude en witwassen. Het doel van de Monitor is om inzicht te bieden in de aard van de georganiseerde criminaliteit in Nederland en de belangrijkste ontwikkelingen daarin. De Monitor richt zich vrijwel uitsluitend op de wijze waarop de criminele samenwerkingsverbanden werken. Er worden geen gegevens over de strafrechtelijke afloop van de zaken verzameld. Het in deze bijdrage beschreven onderzoek biedt daarmee een aanvulling op het reeds in de Monitor uitgevoerde onderzoek.

Het voordeel van het gebruik van de Monitor is dat van de grote meerderheid van de verdachten in deze zaken parketnummers of persoonsgegevens bekend zijn, gegevens die nodig zijn om het verdere verloop door de rechtsgang te kunnen nagaan. Het gebruik van gegevens uit de Monitor brengt echter ook beperkingen mee. De Monitor is geen representatieve steekproef van de georganiseerde criminaliteit in ons land. De keuze voor de opsporingsonderzoeken die in het kader van de Monitor worden geanalyseerd, is 'bewust selectief' (Kruisbergen e.a., 2012, 55). De onderzoekers selecteren juist die opsporingsonderzoeken die 'de meeste toegevoegde waarde hebben voor onze kennis over georganiseerde criminaliteit' (Kruisbergen e.a., 2012, 55). De Monitor kan echter geen generaliserende uitspraken doen over de aard en ontwikkelingen van de georganiseerde criminaliteit in 
Nederland. De bevindingen in deze bijdrage moeten derhalve wel in het licht van de beperkingen van deze Monitor worden bezien.

Voor dit onderzoek maken wij gebruik van alle zaken uit de derde en vierde ronde van de Monitor. In totaal betreft dit 70 zaken, waarin in totaal 1.675 betrokkenen (individuen en rechtspersonen) een rol speelden. Deze betrokkenen zijn niet allemaal ook verdachten, maar kunnen getuigen of overige personen zijn die in het strafrechtelijk onderzoek zijn genoemd. Omdat we in deze bijdrage alleen geïnteresseerd zijn in de strafrechtelijke afloop van de zaken, hebben wij deze overige betrokkenen $(\mathrm{N}=259)$ buiten de analyse gehouden. Ook hebben we alle rechtspersonen $(\mathrm{N}=324)$ uit het analysebestand verwijderd, omdat we, zoals in de inleiding reeds opgemerkt, in deze bijdrage alleen ingaan op de opgelegde vrijheidsstraffen.

Dit resulteerde in een bestand van 1.092 verdachten. Voor al deze verdachten hebben wij via het Wetenschappelijk Onderzoek- en Documentatiecentrum (WODC) gegevens opgevraagd uit de Onderzoek- en Beleidsdatabase Justitiële Documentatie (OBJD) over de strafrechtelijke afdoening. ${ }^{1}$ Deze zoekvraag leverde echter geen compleet beeld op voor alle verdachten. In totaal konden voor 201 verdachten geen gegevens worden teruggevonden in de OBJD. Dat kan verschillende oorzaken hebben.

Ten eerste bevat de Monitor gegevens over de zaken ten tijde van het opsporingsonderzoek. Niet al deze verdachten worden daadwerkelijk bij het OM geregistreerd en zijn daarom ook niet allemaal opgenomen in de OBJD. ${ }^{2}$ Zo bleken verschillende verdachten nog voordat zij vervolgd konden worden, te zijn overleden. Ten tweede staan personen niet in de OBJD geregistreerd als zij in het buitenland zijn vervolgd en berecht voor het delict waarvoor ze in de Monitorzaak voorkomen. Ten derde beschikten wij niet van alle verdachten over een parketnummer of over voldoende persoonsgegevens om gegevens uit de OBJD te kunnen opvragen. Over deze verdachten kwam dus geen informatie terug. Tot slot kunnen ook verschillen in registratie van bijvoorbeeld persoonsgegevens tussen de door ons aangeleverde basisgegevens en de OBJD er de oorzaak van zijn dat sommige verdachten niet terug te vinden waren. Al deze personen $(\mathrm{N}=201)$ hebben we derhalve uit ons analysebestand verwijderd.

Dit resulteerde uiteindelijk in een bestand van 891 verdachten. De OBJD-gegevens bevatten naast informatie over strafrechtelijke antecedenten ook gegevens over de strafrechtelijke afdoening. Gegevens waar de OBJD echter geen inzicht in biedt, zijn de door de officier van justitie geëiste sancties. Om na te gaan welke sancties in de betreffende zaken werden geëist, hebben wij met behulp van de parketnummers de betreffende vonnissen vervolgens opgezocht via Rechtspraak.nl.

Rechtspraak.nl publiceert echter niet alle uitspraken. Voor deze bijdrage hebben wij voor 297 verdachten informatie kunnen vinden over de geëiste en opgelegde sancties in hun strafzaken. Op die verdachten zijn de analyses in deze bijdrage

1 De OBJD is een versleutelde en geanonimiseerde kopie van het JDS die voor wetenschappelijk onderzoek beschikbaar is gesteld (Wartna e.a., 2011).

2 De OBJD bevat informatie over verdachten die door de politie bij het OM worden geregistreerd. 
Tabel 1 Beschrijvend overzicht data

\begin{tabular}{llll}
\hline & $\begin{array}{l}\text { Eerste aanleg } \\
(\mathbf{N}=\mathbf{2 7 2})\end{array}$ & $\begin{array}{l}\text { Hoger beroep } \\
(\mathbf{N}=107)\end{array}$ & $\begin{array}{l}\text { Eerste aanleg en } \\
\text { hoger beroep } \\
(\mathbf{N}=82)\end{array}$ \\
\hline $\begin{array}{l}\text { Type delict } \\
\text { Drugshandel }\end{array}$ & $118(43 \%)$ & $44(41 \%)$ & $28(34 \%)$ \\
$\begin{array}{l}\text { Drugshandel en wit- } \\
\text { wassen }\end{array}$ & $53(20 \%)$ & $16(15 \%)$ & $11(13 \%)$ \\
$\begin{array}{l}\text { Fraude en witwassen } \\
\text { Mensenhandel en/of }\end{array}$ & $48(18 \%)$ & $26(24 \%)$ & $22(27 \%)$ \\
smokkel & $47(17 \%)$ & $19(18 \%)$ & $19(23 \%)$ \\
$\begin{array}{l}\text { Overig } \\
\text { Onbekend }\end{array}$ & $6(2 \%)$ & $2(2 \%)$ & $2(3 \%)$ \\
\hline
\end{tabular}

gebaseerd. Dit betreft drie unieke groepen verdachten. Voor 190 van die verdachten hebben we alleen informatie over eis en vonnis in eerste aanleg, voor 25 verdachten hebben we alleen informatie over het hoger beroep en voor 82 verdachten hebben we informatie over eerste aanleg én hoger beroep.

Concreet betekent dit dat wij in deze bijdrage gegevens presenteren over de geëiste en opgelegde sancties in 272 gevallen in eerste aanleg (190 en 82 gevallen) en 107 ( 25 en 82 gevallen) gevallen in hoger beroep. Daarnaast presenteren we voor 82 gevallen de geëiste en opgelegde sancties in eerste aanleg én hoger beroep. Deze gegevens (tabel 1) zijn vervolgens ingevoerd in Excel en daarna grotendeels handmatig geanalyseerd. Gezien de stand van ons onderzoek, beperken wij ons daarbij vooralsnog hoofdzakelijk tot beschrijvende gegevens en rechte tellingen.

Zoals in de inleiding reeds is toegelicht, betreffen de gegevens waarover we in dit artikel rapporteren een tussenstand in ons onderzoek. Op termijn verwachten we over een groter aantal verdachten in het databestand informatie te hebben over geëiste en opgelegde sancties. Naarmate ons databestand meer gevuld raakt, wordt het mogelijk om uitgebreidere analyses te verrichten.

In de volgende paragrafen presenteren we eerst gegevens over discrepanties tussen strafeis en opgelegde sancties in eerste aanleg $(\mathrm{N}=272)$ en hoger beroep ( $\mathrm{N}=107)$. Daarna gaan we voor de 82 gevallen waarin we de strafeis en opgelegde straf zowel in eerste aanleg als in hoger beroep hebben geanalyseerd, na wat er uiteindelijk van de eis in eerste aanleg is overgebleven. De gegevens worden met concrete voorbeelden uit de vonnissen geïllustreerd.

\section{Resultaten}

Discrepanties tussen geëiste en opgelegde sancties in eerste aanleg en hoger beroep Hoe vaak wijken de door de rechter opgelegde vrijheidsstraffen nu af van de door de officier van justitie geëiste straffen? Zoals hierboven aangegeven, hebben we 
Tabel 2 Discrepanties tussen eis en vonnis in eerste aanleg

\begin{tabular}{|c|c|c|c|c|}
\hline & Lager & Hoger & Gelijk & Totaal \\
\hline Drugshandel & $82(69 \%)$ & $6 \quad(5 \%)$ & $30(26 \%)$ & 118 (43\%) \\
\hline $\begin{array}{l}\text { Drugshandel en } \\
\text { witwassen }\end{array}$ & 40 (75\%) & $3 \quad(6 \%)$ & 10 (19\%) & $53 \quad(20 \%)$ \\
\hline $\begin{array}{l}\text { Fraude en wit- } \\
\text { wassen }\end{array}$ & 37 (77\%) & $5(10 \%)$ & $6(13 \%)$ & $48 \quad(18 \%)$ \\
\hline $\begin{array}{l}\text { Mensenhandel en/ } \\
\text { of -smokkel }\end{array}$ & $43(92 \%)$ & I (2\%) & $3(6 \%)$ & $47 \quad(17 \%)$ \\
\hline \multirow[t]{2}{*}{ Overig } & $5(83 \%)$ & & I (I7\%) & $(2 \%)$ \\
\hline & 207 (76\%) & $15 \quad(6 \%)$ & $50(18 \%)$ & 272 (100\%) \\
\hline
\end{tabular}

272 eisen en vonnissen in eerste aanleg geanalyseerd. Uit de analyse van alle 272 gevallen blijkt dat de gemiddelde door de rechter opgelegde vrijheidsstraf in aantal maanden $(M=42.45, S E=2.11)$ significant lager is dan de geëiste gevangenisstraf $(\mathrm{M}=60.91, \mathrm{SE}=2.57)$. $^{3}$

Tabel 2 splitst deze gegevens vervolgens uit en laat zien dat de rechter in 18 procent van die 272 gevallen een vrijheidsstraf oplegt gelijk aan de eis van de officier van justitie. Dat betekent dat in 82 procent van de gevallen de door de rechter opgelegde sanctie afwijkt van de eis van de officier van justitie. Bovendien wijkt de door de rechter opgelegde sanctie in driekwart van de gevallen, 76 procent, naar beneden af. Met andere woorden: 207 verdachten kregen in eerste aanleg een lagere straf opgelegd dan was geëist. Daarentegen kregen 15 verdachten een hogere straf opgelegd.

In hoger beroep zien we een vergelijkbaar beeld (tabel 3). Uit de analyse van de 107 verdachten van wie we eis en vonnis in hoger beroep hebben bestudeerd, blijkt dat in hoger beroep het vonnis in 83 procent van de gevallen afwijkt van de eis door het OM. In 18 zaken (17 procent) kwam de rechter tot dezelfde vrijheidsstraf als de officier van justitie. Ook in hoger beroep wijkt de rechter meestal naar beneden af. Driekwart van de verdachten (78 procent) kreeg een lagere vrijheidsstraf opgelegd dan geëist. Vijf verdachten kregen in hoger beroep een hogere straf opgelegd dan geëist. Ook hier laat de analyse van alle 107 gevallen zien dat de gemiddeld door de rechter opgelegde gevangenisstraf in aantal maanden $(\mathrm{M}=45.99, \mathrm{SE}=3.58)$ significant lager is dan de geëiste gevangenisstraf $(\mathrm{M}=71.82$, $\mathrm{SE}=4.94) .{ }^{4}$

\section{De verschillen nader bekeken}

Uit het bovenstaande komt naar voren dat de door de rechter opgelegde vrijheidsstraf in eerste aanleg en in hoger beroep in meer dan 80 procent van de gevallen afwijkt van de eis van de officier van justitie. In de meeste gevallen betreft het 
Tabel 3 Discrepanties tussen eis en vonnis in hoger beroep

\begin{tabular}{|c|c|c|c|c|}
\hline & Lager & Hoger & Gelijk & Totaal \\
\hline Drugshandel & 34 (77\%) & $2(5 \%)$ & $8(18 \%)$ & $44 \quad(41 \%)$ \\
\hline $\begin{array}{l}\text { Drugshandel en } \\
\text { witwassen }\end{array}$ & 15 (94\%) & & I (6\%) & $16 \quad(15 \%)$ \\
\hline $\begin{array}{l}\text { Fraude en wit- } \\
\text { wassen }\end{array}$ & $14 \quad(54 \%)$ & $3(11 \%)$ & 9 (35\%) & 26 (24\%) \\
\hline $\begin{array}{l}\text { Mensenhandel en/ } \\
\text { of -smokkel }\end{array}$ & $19(100 \%)$ & & & $19 \quad(18 \%)$ \\
\hline \multirow[t]{2}{*}{ Overig } & $2(100 \%)$ & & & $(2 \%)$ \\
\hline & 84 (78\%) & $5(5 \%)$ & $18(17 \%)$ & $107(100 \%)$ \\
\hline
\end{tabular}

hier afwijkingen naar beneden. In beide instanties werd in driekwart van de gevallen een lagere vrijheidsstraf opgelegd dan was geëist. Een volgende vraag is dan natuurlijk: hoe sterk wijkt de door de rechter opgelegde vrijheidsstraf af van de geëiste? Om die vraag te beantwoorden hebben we de duur van de geëiste en opgelegde vrijheidsstraffen met elkaar vergeleken in die gevallen waarin de rechter lager strafte dan was geëist (tabel 4 en 5). Wij illustreren de bevindingen met voorbeelden uit de casuïstiek.

Zoals reeds in de inleiding beschreven, gaat het bij georganiseerde criminaliteit doorgaans om ernstige misdrijven die een zwaar beslag leggen op de capaciteit van politie en justitie (Kruisbergen e.a., 2012; Duijneveldt e.a., 2012). Wij hebben daarom eerst onderzocht hoe vaak het voorkomt dat zaken resulteren in vrijspraak waar vrijheidsstraffen werden geëist.

Tabel 4 laat zien dat in eerste aanleg 10 zaken (5 procent) in vrijspraak resulteerden waar vrijheidsstraffen waren geëist. In hoger beroep (tabel 5) lag dit percentage iets hoger: in 11 zaken (13 procent) ging de verdachte vrijuit. Vrijspraak komt dus niet vaak voor en is soms het onvermijdelijke gevolg van een gebrek aan bewijs of fouten die gemaakt zijn tijdens het opsporingsproces. In een zaak waarin de verdachten vervolgd werden voor de handel in drugs en het witwassen van het daarmee verkregen vermogen had de officier van justitie tegen twee verdachten respectievelijk acht en twaalf jaar gevangenisstraf geëist. In hoger beroep sprak het hof beide verdachten vrij omdat het dossier 'op essentiële punten voor de bewijsvoering van beide feiten onvolledig is, op meerdere onderdelen onjuistheden of op zijn minst onzorgvuldigheden bevat, en overigens ook onvoldoende overzichtelijk is'.

Vervolgens zijn we nagegaan hoe groot het verschil was tussen de geëiste en opgelegde vrijheidsstraffen naar de duur van de gevangenisstraf. Tabel 4 laat voor de 207 gevallen in eerste aanleg waarin er een lagere straf werd opgelegd dan geëist, zien dat er gemiddeld een gevangenisstraf werd geëist van vijf jaar en acht maanden, waarbij de strafeis varieerde van een maand tot twintig jaar gevangenisstraf. Daartegenover werd gemiddeld een vrijheidsstraf opgelegd van drie jaar en zeven maanden, variërend van vrijspraak tot een gevangenisstraf van vijftien jaar. 
Tabel 4 Discrepanties tussen strafeis en strafmaat naar strafduur in eerste aanleg

\begin{tabular}{|c|c|c|c|c|c|}
\hline \multirow[t]{2}{*}{$\mathrm{N}=\mathbf{2 0 7}$} & \multicolumn{2}{|l|}{ Eis } & \multicolumn{2}{|l|}{ Vonnis } & \multirow{2}{*}{$\begin{array}{l}\text { Vrijspraak } \\
\mathrm{N}=10(5 \%)\end{array}$} \\
\hline & Gem. & Range & Gem. & Range & \\
\hline $\begin{array}{l}<1 \text { jr lager } N=50 \\
(24 \%)\end{array}$ & $2 \mathrm{jr}, 8 \mathrm{mnd}$ & $\begin{array}{l}\text { I mnd-I0 jr, } 4 \\
\text { mnd }\end{array}$ & $2 \mathrm{jr}, 3 \mathrm{mnd}$ & $0-10 \mathrm{jr}$ & 3 \\
\hline $\begin{array}{l}\text { I-2 jr lager } N=87 \\
(42 \%)\end{array}$ & $5 \mathrm{jr}, 8 \mathrm{mnd}$ & $\mathrm{I}-16 \mathrm{jr}$ & $4 \mathrm{jr}, 2$ mnd & $0-15 \mathrm{jr}$ & 5 \\
\hline $\begin{array}{l}2-5 \mathrm{jr} \text { lager } \mathrm{N}=58 \\
(28 \%)\end{array}$ & $7 \mathrm{jr}$ & $3-14 \mathrm{jr}$ & $3 \mathrm{jr}, 10 \mathrm{mnd}$ & $0-11 \mathrm{jr}$ & 2 \\
\hline $\begin{array}{l}>5 \text { jr lager } N=12 \\
(6 \%)\end{array}$ & II jr, I mnd & $7-20 \mathrm{jr}$ & $3 \mathrm{jr}, 8 \mathrm{mnd}$ & 6 mnd-9 jr & \\
\hline Totaal & 5 jr, 8 mnd & I mnd-20 jr & $3 \mathrm{jr}, 7 \mathrm{mnd}$ & $0-I 5$ jr & \\
\hline
\end{tabular}

Tabel 5 Discrepanties tussen strafeis en strafmaat naar strafduur in hoger beroep

\begin{tabular}{|c|c|c|c|c|c|}
\hline \multirow[t]{2}{*}{$N=84$} & \multicolumn{2}{|l|}{ Eis } & \multicolumn{2}{|l|}{ Vonnis } & \multirow{2}{*}{$\begin{array}{l}\text { Vrijspraak } \\
N=\text { II (13\%) }\end{array}$} \\
\hline & Gem. & Range & Gem. & Range & \\
\hline $\begin{array}{l}<1 \text { jr lager } N=10 \\
(12 \%)\end{array}$ & $2 \mathrm{jr}, 4 \mathrm{mnd}$ & I mnd-9 jr & $\mathrm{I} \mathrm{jr}, 9 \mathrm{mnd}$ & $0-8 \mathrm{jr}, 6 \mathrm{mnd}$ & 2 \\
\hline $\begin{array}{l}\text { I-2 jr lager } N=33 \\
(39 \%)\end{array}$ & $5 \mathrm{jr}, 6$ mnd & $\mathrm{I}-10 \mathrm{jr}$ & $4 \mathrm{jr}, 2$ mnd & $0-9 \mathrm{jr}$ & 3 \\
\hline $\begin{array}{l}2-5 \mathrm{jr} \text { lager } \mathrm{N}=32 \\
(38 \%)\end{array}$ & 7 jr, 9 mnd & $2 \mathrm{jr}, 4 \mathrm{mnd}-\mathrm{I} 6 \mathrm{jr}$ & $4 \mathrm{jr}, 6 \mathrm{mnd}$ & $0-12 \mathrm{jr}$ & 4 \\
\hline $\begin{array}{l}>5 \text { jr lager } N=9 \\
(11 \%)\end{array}$ & $12 \mathrm{jr}, 4 \mathrm{mnd}$ & $8-20 \mathrm{jr}$ & $3 \mathrm{jr}, 7 \mathrm{mnd}$ & $\begin{array}{l}0-10 \mathrm{jr}, 6 \\
\text { mnd }\end{array}$ & 2 \\
\hline Totaal & $6 \mathrm{jr}, 9 \mathrm{mnd}$ & I mnd-20 jr & $3 \mathrm{jr}, \mathrm{I} / \mathrm{mnd}$ & $0-12 \mathrm{jr}$ & \\
\hline
\end{tabular}

In hoger beroep zien we een vergelijkbaar beeld. Tabel 5 toont de verschillen tussen geëiste en opgelegde straffen voor de 84 gevallen waarin de rechter lager strafte dan geëist. Gemiddeld werd een gevangenisstraf geëist van zes jaar en negen maanden, variërend van een maand tot twintig jaar. De gemiddelde gevangenisstraf die werd opgelegd, betrof drie jaar en elf maanden, variërend van vrijspraak tot twaalf jaar.

Wanneer we vervolgens kijken naar de discrepanties tussen strafeis en strafmaat voor vier categorieën van lagere straffen, dan zien we dat in respectievelijk 66 procent van de gevallen in eerste aanleg en 51 procent in hoger beroep de verschillen betrekkelijk klein zijn en de rechter tot twee jaar lager straft dan geëist. Er zijn echter ook zaken waarin de rechter fors lagere straffen oplegt. In 28 procent van de gevallen in eerste aanleg en in 38 procent in hoger beroep kregen de verdachten een gevangenisstraf opgelegd die twee tot vijf jaar lager was dan 
geëist. Respectievelijk 6 en 11 procent van de verdachten kregen zelfs gevangenisstraf van vijf of meer jaren lager. Bij een gemiddelde eis van elf jaar en een maand legde de rechter in eerste aanleg gemiddeld drie jaar en acht maanden gevangenisstraf op, een verschil van zeven jaar en vijf maanden. In hoger beroep is dat verschil nog iets groter: bij een gemiddelde eis van twaalf jaar en vier maanden legde de rechter gemiddeld drie jaar en zeven maanden op (een verschil van acht jaar en negen maanden). De opgelegde straf is dus gemiddeld minder dan de helft van de geëiste straf.

In een zaak waarin de verdachten terechtstonden voor grootschalige handel in xtc, kreeg een verdachte 422 dagen gevangenisstraf opgelegd waar de officier van justitie acht jaar had geëist. De reden hiervoor was dat de verdachte tweemaal langdurig in hongerstaking was geweest en eenmaal in dorststaking, waardoor hij een hersenbeschadiging had opgelopen. Enig zicht op herstel ontbrak en daarom viel de gevangenisstraf zo veel lager uit.

In een andere zaak betreffende de productie en handel in xtc had de officier van justitie in eerste aanleg een gevangenisstraf van twaalf jaar geëist. De rechtbank legde vervolgens tien jaar gevangenisstraf op. Het hoger beroep liep echter onnodige vertraging op, doordat het $\mathrm{OM}$ een door een infiltrant gebruikt telefoonnummer niet wilde verantwoorden. Dit nam het hof mee in de strafoplegging, waardoor uiteindelijk een gevangenisstraf van zeven jaar werd opgelegd.

\section{De verschillen door de strafrechtelijke keten heen}

$\mathrm{Nu}$ we de verschillen tussen eis en vonnis in eerste aanleg en hoger beroep separaat hebben bekeken, onderzoeken we het verloop van de zaken door de strafrechtelijke keten heen. Hoe is de situatie tussen eerste aanleg en hoger beroep? We kijken daarbij eerst naar de relatie tussen de eis in hoger beroep en de afdoening in eerste aanleg. Haakt de officier in hoger beroep in op het lagere vonnis van de rechter in eerste aanleg of is zijn eis in hoger beroep ongeveer gelijk aan de eis die zijn collega-officier in eerste aanleg had geformuleerd? Een antwoord op deze vraag kan worden gevonden bij de 82 gevallen waarvoor we de eisen en vonnissen in eerste aanleg én hoger beroep hebben geanalyseerd.

\section{Tabel 6 Eis hoger beroep versus vonnis eerste aanleg}

\begin{tabular}{|c|c|c|c|c|}
\hline & Lager & Hoger & Gelijk & Totaal \\
\hline Drugshandel & & 20 (7I\%) & $8(29 \%)$ & $28(34 \%)$ \\
\hline $\begin{array}{l}\text { Drugshandel en } \\
\text { witwassen }\end{array}$ & I $\quad(9 \%)$ & $4 \quad(36 \%)$ & $6(55 \%)$ & II (I3\%) \\
\hline $\begin{array}{l}\text { Fraude en wit- } \\
\text { wassen }\end{array}$ & 3 (14\%) & 13 (59\%) & $6(27 \%)$ & $22(27 \%)$ \\
\hline $\begin{array}{l}\text { Mensenhandel en/ } \\
\text { of -smokkel }\end{array}$ & $(5 \%)$ & I6 (84\%) & $2(11 \%)$ & $19(23 \%)$ \\
\hline Overig & & 2 (100\%) & & (3\%) \\
\hline Totaal & $5 \quad(6 \%)$ & $55 \quad(67 \%)$ & $22(27 \%)$ & 82 (1 $00 \%)$ \\
\hline
\end{tabular}


Uit tabel 6 blijkt dat de officier in 67 procent van de gevallen in hoger beroep een hogere straf eist dan in eerste aanleg door de rechter is opgelegd. In 6 procent van de gevallen valt de eis in hoger beroep juist lager uit dan door de rechter in eerste aanleg is opgelegd en in 27 procent van de gevallen sluit de in hoger beroep geëiste straf aan bij de in eerste aanleg opgelegde straf. De officier gaat in hoger beroep niet mee met het vonnis in eerste aanleg en houdt in de meeste gevallen vast aan de eis in eerste aanleg (niet in tabel).

Vervolgens hebben we de opgelegde sancties in eerste aanleg en hoger beroep met elkaar vergeleken (tabel 7).

Tabel $7 \quad$ Sanctie opgelegd in hoger beroep versus sanctie in eerste aanleg

\begin{tabular}{lcccc}
\hline & Lager & Hoger & Gelijk & \multicolumn{2}{l}{ Totaal } \\
\hline $\begin{array}{l}\text { Drugshandel } \\
\begin{array}{l}\text { Drugshandel en } \\
\text { witwassen }\end{array}\end{array}$ & $8(72 \%)$ & $4(14 \%)$ & $4(14 \%)$ & 28 (34\%) \\
$\begin{array}{l}\text { Fraude en wit- } \\
\text { wassen }\end{array}$ & II (50\%) & $5(23 \%)$ & $6(27 \%)$ & $22 \quad(27 \%)$ \\
$\begin{array}{l}\text { Mensenhandel } \\
\text { en/of -smokkel }\end{array}$ & $12(63 \%)$ & $4(21 \%)$ & $3(16 \%)$ & $19 \quad(23 \%)$ \\
$\begin{array}{l}\text { Overig } \\
\text { I (50\%) }\end{array}$ & $\mathbf{5 2 ( 6 3 \% )}$ & $13(16 \%)$ & $17(21 \%)$ & $\mathbf{8 2 ( 1 0 0 \% )}$ \\
\hline
\end{tabular}

In hoger beroep kreeg 21 procent van de verdachten dezelfde straf als in eerste aanleg en 16 procent een hogere straf dan in eerste aanleg. Ook hier blijkt echter dat in meer dan de helft van de gevallen (63 procent) de rechter in hoger beroep een lagere straf oplegt dan de rechter in eerste aanleg.

Wanneer we de duur van de opgelegde vrijheidsstraffen in eerste aanleg en hoger beroep vervolgens met elkaar vergelijken (tabel 8), valt allereerst op dat 13 procent van de verdachten in hoger beroep wordt vrijgesproken, terwijl zij in eerste aanleg nog schuldig werden bevonden voor één of meer tenlastegelegde feiten.

In de 52 gevallen waarin de rechter in hoger beroep tot een lagere straf kwam dan in eerste aanleg, betrof het verschil gemiddeld een jaar en tien maanden (drie jaar en acht maanden versus vijf jaar en zes maanden). In 79 procent van die gevallen was het verschil beperkt tot twee jaar tussen de straf in eerste aanleg en hoger beroep. In 11 gevallen waren de verschillen groter, variërend van twee jaar verschil tot meer dan vijf jaar verschil.

In een zaak waarin de verdachten werden vervolgd voor de invoer van cocaïne uit Midden- en Zuid-Amerika, eiste de officier van justitie zowel in eerste aanleg als in hoger beroep negen jaar gevangenisstraf tegen een van de hoofddaders. Hoewel de rechter in eerste aanleg nog een hogere gevangenisstraf oplegde van tien jaar, bleef daar in hoger beroep vier jaar en zes maanden gevangenisstraf van over.

Ook in een andere zaak betreffende de grootschalige en internationale handel in xtc, amfetamine, hasjiesj en marihuana liepen de geëiste en opgelegde straffen in eerste aanleg en hoger beroep sterk uiteen. In eerste aanleg werd tegen een van de 
Tabel $8 \quad$ Opgelegde gevangenisstraf in hoger beroep ten opzichte van de straf in eerste aanleg naar strafduur

\begin{tabular}{|c|c|c|c|c|c|}
\hline \multirow[t]{2}{*}{$\mathrm{N}=52$} & \multicolumn{2}{|c|}{ Vonnis eerste aanleg } & \multicolumn{2}{|c|}{ Vonnis hoger beroep } & \multirow{2}{*}{$\begin{array}{l}\text { Vrijspraak } \\
\mathrm{N}=7 \text { (13\%) }\end{array}$} \\
\hline & Gem. & Range & Gem. & Range & \\
\hline $\begin{array}{l}<1 \text { jr lager } N=14 \\
(27 \%)\end{array}$ & $\mathrm{I} \mathrm{jr}, 8 \mathrm{mnd}$ & 4 mnd-4 jr, 6 mnd & I jr, I mnd & $0-4 \mathrm{jr}$ & 3 \\
\hline $\begin{array}{l}\text { I-2 jr lager } N=27 \\
(52 \%)\end{array}$ & $5 \mathrm{jr}, 7 \mathrm{mnd}$ & $1 \mathrm{jr}, 6$ mnd- $13 \mathrm{jr}$ & $4 \mathrm{jr}, 2 \mathrm{mnd}$ & $\begin{array}{l}0-11 \mathrm{jr}, 8 \\
\text { mnd }\end{array}$ & 2 \\
\hline $\begin{array}{l}2-5 \text { jr lager } N=10 \\
(19 \%)\end{array}$ & $7 \mathrm{jr}, 7$ mnd & $2 \mathrm{jr}, 4 \mathrm{mnd}-15 \mathrm{jr}$ & $4 \mathrm{jr}, 6 \mathrm{mnd}$ & $0-12 \mathrm{jr}$ & 2 \\
\hline $\begin{array}{l}>5 \text { jr lager } N=I \\
(2 \%)\end{array}$ & $10 \mathrm{jr}$ & N.v.t. & $4 \mathrm{jr}, 6 \mathrm{mnd}$ & N.v.t. & \\
\hline Totaal & $5 \mathrm{jr}, 6 \mathrm{mnd}$ & 4 mnd- 15 jr & $3 \mathrm{jr}, 8 \mathrm{mnd}$ & $0-12 \mathrm{jr}$ & 7 \\
\hline
\end{tabular}

verdachten een gevangenisstraf van elf jaar geëist. Door de rechter in eerste aanleg werd vervolgens een gevangenisstraf van acht jaar en zes maanden opgelegd. In hoger beroep eiste de officier twaalf jaar gevangenisstraf en daar bleef uiteindelijk zeven jaar van over.

Niet alleen in drugszaken zijn de straffen in hoger beroep soms veel lager dan in eerste aanleg. In het geval van een crimineel samenwerkingsverband dat mensen vanuit China naar West-Europa smokkelde, werd tegen een van de hoofdverdachten in eerste aanleg tien jaar en acht maanden gevangenisstraf geëist. De rechtbank veroordeelde deze verdachte tot drie jaar gevangenisstraf. In hoger beroep eiste de officier opnieuw tien jaar gevangenisstraf, maar ook het hof veroordeelde de verdachte tot een gevangenisstraf van drie jaar.

Samengevat: bovenstaande voorbeelden laten zien dat de eerder geconstateerde daling tussen eis en vonnis in eerste aanleg zich ook in hoger beroep doorzet. De opgelegde gevangenisstraffen in hoger beroep zijn in iets meer dan de helft van de gevallen lager dan in eerste aanleg. Tegelijkertijd kan er niet worden gesproken van een lineaire daling. De eis in hoger beroep vervult namelijk geen verbindende 'scharnierfunctie' tussen de straffen in eerste aanleg en hoger beroep. De eis in hoger beroep haakt namelijk niet in op de straf in eerste aanleg, maar op de eis in eerste aanleg.

Ook laten de gepresenteerde gegevens zien dat de opgelegde gevangenisstraffen in eerste aanleg en hoger beroep aanzienlijk kunnen verschillen. Verdachten die in hoger beroep gaan, krijgen gemiddeld een gevangenisstraf opgelegd die een jaar en tien maanden lager is dan in eerste aanleg. Dat roept de vraag op hoe deze verschillen te duiden zijn.

Deze vraag is op basis van ons huidige databestand moeilijk te beantwoorden. Zoals uit enkele van de gepresenteerde voorbeelden blijkt, zijn er soms logische verklaringen voor de discrepanties tussen eis en opgelegde straf en tussen de opgelegde sancties in eerste aanleg en hoger beroep. Deelvrijspraken, lange doorlooptijden, een gebrek aan bewijs en vormfouten tijdens het opsporingsproces verklaren voor een deel waarom de rechter lagere straffen oplegt. Een ander type 
verklaring is dat de officier van justitie al bij de formulering van de strafeis anticipeert op het gegeven dat de rechter vaak een lagere straf oplegt en dus hoog inzet. Tegelijkertijd blijkt uit de bestudeerde vonnissen dat - overeenkomstig eerder onderzoek naar straftoemeting (Verstege \& Van Wingerden, 2009; Van Wingerden \& Nieuwbeerta, 2010; Boone \& Korf, 2010) - het vonnis vaak nauwelijks inzicht geeft in de precieze beweegredenen van de rechter om een bepaalde sanctie op te leggen. Vrijwel altijd wordt een standaardmotivering gebruikt.

Lang niet altijd wordt dus duidelijk waarom rechters een bepaalde sanctie opleggen en waarom ze bijvoorbeeld kiezen voor een gevangenisstraf van negen jaar in plaats van tien jaar. In twee van de hierboven genoemde voorbeelden kwam het hof bijvoorbeeld op grond van exact dezelfde feiten en omstandigheden die de rechtbank in eerste aanleg hanteerde tot een schuldigverklaring. Ook werd dezelfde standaardmotivering gebruikt om de strafmaat te motiveren. Toch legde het hof gevangenisstraffen op die respectievelijk vijfenhalf jaar en een jaar korter waren dan in eerste aanleg. Dit zijn ogenschijnlijk kleine verschillen, maar voor de verdachte maakt een jaar meer of minder gevangenisstraf vanzelfsprekend een groot verschil.

\section{Conclusie en discussie}

In de afgelopen 25 jaar is door politie en justitie sterk geïnvesteerd in de strijd tegen de georganiseerde criminaliteit (Kruisbergen e.a., 2012; Boerman e.a., 2012; Smits e.a., 2013). In de Veiligheidsagenda 2015-2018 van het ministerie van Veiligheid en Justitie (2014) krijgt de aanpak van ondermijnende criminaliteit zelfs een centrale plek. Dit roept de vraag op waartoe de geleverde inspanningen hebben geleid.

In deze bijdrage hebben wij onderzocht of en in hoeverre er discrepanties bestaan tussen strafeisen van de officier van justitie en de opgelegde vrijheidsstraffen door de rechter, in eerste aanleg en in hoger beroep. Dit is een ogenschijnlijk simpele vraag, maar deze kan slechts na veel zoekwerk in de politiële en justitiële gegevensbestanden worden beantwoord.

Wij hebben gebruik gemaakt van de 70 meest recente zaken uit de Monitor Georganiseerde Criminaliteit. Met behulp van dadergegevens hebben wij gepoogd zowel de eis als het vonnis in eerste aanleg te vinden; vervolgens werd dezelfde exercitie ondernomen voor de verdachten die in hoger beroep gingen.

De belangrijkste bevindingen uit dit onderzoek zijn dat de rechter lager straft dan geëist en dat deze daling zich in hoger beroep doorzet. In driekwart van de gevallen in eerste aanleg en hoger beroep legt de rechter een lagere straf op dan door de officier van justitie geëist. In eerste aanleg betreft het verschil gemiddeld twee jaar en een maand, in hoger beroep twee jaar en tien maanden. Voor wat betreft de 82 gevallen waarvoor we de strafrechtsketen in kaart hebben gebracht, zien we dat de rechter in hoger beroep in meer dan de helft van de gevallen lager straft dan de rechter in eerste aanleg. Gemiddeld betrof het verschil een jaar en tien maanden. Deze bevindingen wijken af van de in de literatuur beschreven consensus tussen strafeis en strafmaat bij minder ernstige en veelvoorkomende vormen 
van criminaliteit. In de meeste strafzaken straft de rechter conform de eis van de officier van justitie, zo blijkt uit Verkleij en Meijer (2015, 39-40).

Georganiseerde-misdaadzaken zijn in het algemeen complexe zaken vanwege de omvang (groot aantal verdachten per zaak) en de normatief-juridische problemen (bewijsvoering, kroongetuigen, internationale juridische samenwerking) waarvoor de officier en de rechter gesteld worden. Bovendien zijn de daders vaak goed in staat om zich juridisch te wapenen tegen de verdenkingen aan hun adres door het inhuren van goede advocaten die hen zouden kunnen helpen bij de verdediging.

De strafrechtelijke aanpak van georganiseerde misdaad doet - met andere woorden - een zwaar beroep op de verwerkingscapaciteit van het strafrechtelijk systeem (Ministerie van Veiligheid en Justitie, 2008, 1). Tegelijkertijd is het van belang dat deze delicten worden afgedaan op een wijze die past bij de ernst en de maatschappelijke aandacht die deze zaken genereren. In de literatuur wordt veel aandacht besteed aan de selectieve filterwerking van het strafrecht (Van de Bunt, 1992; Algemene Rekenkamer, 2012; Van Tulder e.a., 2015). Hiermee wordt de situatie bedoeld dat naarmate zaken complexer worden, de kans op uitval uit de keten door middel van buitengerechtelijke afdoeningen, vrijspraken en ontslagen van rechtsvervolging groter wordt. Het strafrechtelijk systeem behandelt dan ook vooral zaken die volgens vaste procedures verwerkt kunnen worden. Dit zijn over het algemeen betrekkelijk eenvoudige, vaak terugkerende commune misdrijven van personen die het minste tegenspel bieden (Van de Bunt, 1992, 10). Daarentegen zouden plegers van complexe misdrijven, die wel tegenspel bieden, hun passende straf wel eens kunnen ontlopen.

Dit onderzoek kan die beeldvorming niet geheel ontkrachten. De verschillen tussen geëiste en opgelegde vrijheidsstraffen zijn aanzienlijk en we zien daarnaast een duidelijk verschil tussen opgelegde sancties in eerste aanleg en in hoger beroep.

Tot dusver hebben wij voor 297 van de 891 verdachten in ons databestand gegevens over geëiste en opgelegde straffen verzameld. Hoewel we in het vervolg van ons onderzoek meer data hopen te kunnen presenteren over een grotere groep verdachten, past terughoudendheid bij de interpretatie van de resultaten. Zo beperkt onder meer het gebruik van de gegevens uit de Monitor de mogelijkheid tot generaliseren. Ook hebben wij ons door de complexiteit van de dataverzameling vooralsnog vooral beperkt tot rechte tellingen en beschrijvende gegevens.

Tegelijkertijd hebben wij laten zien dat dit type onderzoek schaars is. Gegevens over geëiste en opgelegde straffen zijn bijvoorbeeld op verschillende plekken opgeslagen, wat het verzamelen van deze gegevens een tijdrovende klus maakt. De gegevens die we hier presenteren, bieden dan ook een uniek eerste inzicht in de strafrechtelijke afhandeling van georganiseerde criminaliteit.

Ons onderzoek laat niettemin nog veel vragen onbeantwoord. Zo hebben we in deze bijdrage alleen gegevens over vrijheidsstraffen beschreven. De geldboetes hebben we vooralsnog buiten de analyse gelaten. Nadere analyses zullen moeten uitwijzen of ten aanzien van die sanctie eenzelfde beeld te zien is. Ook de vraag of de bevindingen opgaan voor alle typen delicten kunnen we op basis van de gegevens waarover we hier rapporteren nog niet beantwoorden. Niettemin is het 
belangrijk om dit nader te onderzoeken. Zo geldt bijvoorbeeld voor mensenhandel dat de strafbedreiging daarvoor de afgelopen jaren meerdere keren is verhoogd (Nationaal Rapporteur Mensenhandel, 2013). Ook is er enkele jaren geleden besloten om mensenhandelzaken door gespecialiseerde rechters te laten behandelen, om zo al te grote verschillen in de afhandeling van zaken te voorkomen (Nationaal Rapporteur Mensenhandel, 2012). Het roept de vraag op hoe de in deze bijdrage gepresenteerde verschillen te duiden zijn. Wat betekent het inzetten van gespecialiseerde rechters voor de discrepanties tussen geëiste en opgelegde sancties, welke argumenten geven rechters voor het afwijken van de strafeis en hoe kijken officieren van justitie tegen deze discrepanties aan?

Het is op basis van dit onderzoek nog niet mogelijk om antwoord te geven op deze vragen. Een kwalitatieve vervolgstudie, bestaande uit interviews met officieren van justitie en rechters, zal hierin meer inzicht bieden.

\section{Literatuur}

Albanese, J.S. (2011). Sentencing organized crime offenders. In: J.S. Albanese (ed.). Organized crime in our times. New York: Routledge, 339-360.

Algemene Rekenkamer (2012). Prestaties in de strafrechtsketen. Den Haag: Algemene Rekenkamer.

Boerman, F., Grapendaal, M., Nieuwenhuis, F. \& Stoffers, E. (2012). Nationaal dreigingsbeeld 2012. Georganiseerde criminaliteit. Zoetermeer: KLPD-IPOL.

Boone, M. \& Korf, D.J. (2010). Bestraffing van cocaïnesmokkelaars. Tijdschrift voor Criminologie, 52(3), 239-257.

Bosmans, M. \& Pemberton, A. (2012). Straftoemeting bij geweld tegen kwalificerende slachtoffers: een replicatie-studie. Tilburg: INTERVICT.

Brouwers, M. \& Eggen, A.Th.J. (2013). Berechting. In: M.M. Van Rosmalen, S.N. Kalidien \& N.E. De Heer-De Lange (ed.). Criminaliteit en rechtshandhaving 2012. Ontwikkelingen en samenhangen. Den Haag: Boom Juridische uitgevers, 133-151.

Bunt, H.G. van de (1992). Selectiviteit in strafrechtelijke organisaties. In: Studieboek rechtssociologie Open Universiteit Heerlen. Heerlen: Open Universiteit, 1-13.

Bunt, H.G. van de \& Gelder, J.L. van (2012). The Dutch prosecution service. Crime and Justice. A Review of Research, 41, 117-140.

Bunt, H.G. van de \& Kleemans, E.R. (2007). Georganiseerde criminaliteit in Nederland: derde rapportage op basis van de Monitor Georganiseerde Criminaliteit. Den Haag: WODC.

Campbell, L. (2013). Organised crime and the law: a comparative analyses. Oxford: Hart Publishing.

Desroches, F. (2013). The use of organized crime and conspiracy laws in the investigation and prosecution of criminal organizations. Policing, 4, 401-410.

Duijneveldt, I. van, Haagsma, J., Klein Haneveld, R., Knapp, M., Kop, N., Smidts, I., Snel, G. \& Wilders, O. (2012). Administratieve lastendruk bij opsporing zware en georganiseerde criminaliteit. Een nulmeting. Utrecht/Apeldoorn: Politieacademie.

Jorritsma, E. \& Steenbergen, E. van (5 april 2014). Mensenhandel bewijzen is erg lastig. NRC Handelsblad.

Kleemans, E.R., Berg, E.I.A.M. van den \& Bunt, H.G. van de (1998). Georganiseerde criminaliteit in Nederland. Rapportage op basis van de WODC-monitor. Den Haag: WODC.

Kleemans, E.R., Brienen, M.E.I. \& Bunt, H.G. van de (2002). Georganiseerde criminaliteit in Nederland. Tweede rapportage op basis van de WODC-monitor. Den Haag: WODC. 
Kort, J. \& Terpstra, J. (2015a). Vertrouwen van politiemensen in de strafrechtspleging. Proces, 94(3), 162-174.

Kort, J. \& Terpstra, J. (2015b). Onvrede van politiemensen over de strafrechtspleging. Het Tijdschrift voor de Politie, 77(1), 6-10.

Kort, J., Fedorova, M.I. \& Terpstra, J. (2014). Politiemensen over het strafrecht. Apeldoorn: Politie \& Wetenschap.

Kruisbergen, E.W., Bunt, H.G. van de \& Kleemans, E.R. (2012). Georganiseerde criminaliteit in Nederland. Vierde rapportage op basis van de Monitor Georganiseerde Criminaliteit. Den Haag: Boom Lemma uitgevers.

Lodewijks, I.A.J., Laxminarayan, M.S., Aa, S. van der \& Pemberton, A. (2010). Straftoemeting bij geweld tegen kwalificerende slachtoffers. Tilburg: INTERVICT.

Ministerie van Veiligheid en Justitie (2008). Programma Versterking Aanpak Georganiseerde Criminaliteit. Den Haag: Ministerie van Veiligheid en Justitie.

Ministerie van Veiligheid en Justitie (2014). Veiligheidsagenda 2015-2018. www. rijksoverheid.nl/documenten/rapporten/2014/09/17/bijlageveiligheidsagenda-2015 $-2018$.

Nationaal Rapporteur Mensenhandel (2012). Mensenhandel. Jurisprudentie mensenhandelzaken 2009-2012. Een analyse. Den Haag: BNRM.

Nationaal Rapporteur Mensenhandel (2013). Is artikel 273f Sr nog steeds zo ingewikkeld? www.nationaalrapporteur.nl/actueel/nieuws/2013/20130604-is-artikel-273f-nogsteeds-zo-ingewikkeld.aspx.

Nieuwbeerta, P. \& Wingerden, S. van (2006). Geëiste en opgelegde sancties bij moord en doodslag, 1993-2004. Trema, 7, 280-285.

Nieuwenhuis, F. \& Pannekoek, M. (2012). Werkwijzen van georganiseerde criminaliteit. Verslag van een onderzoek voor het Nationaal dreigingsbeeld 2012. Zoetermeer: Dienst IPOL.

Paoli, L. (ed.) (2014). The Oxford handbook of organized crime. Oxford: Oxford University Press.

Slotboom, A., Koppe, H., Passchier, I., Jonge, L. de \& Meijer, R. (1992). De relatie tussen eis en vonnis; strafvordering en straftoemeting in vier arrondissementen. Justitiële verkenningen, 18(8), 59-71.

Smits, J., Sibma, A., Roodnat, J. \& Schudde, B. (2013). Bestuurlijke aanpak georganiseerde criminaliteit. Onderzoek naar de stand van zaken in 2012. Den Haag: WODC.

Tulder, F. van, Meijer, R., Kalidien, S. \& Verkleij, C. (2015). De strafrechtsketen in samenhang. In: S. Kalidien en N. de Heer-de Lange (red.). Criminaliteit en rechtshandhaving 2014. Ontwikkelingen en samenhangen. Den Haag: Boom Juridische uitgevers, 55-64.

Verkleij, C.M.P. \& Meijer, R.F. (2015). Berechting. In: S. Kalidien \& N. de Heer-de Lange (red.). Criminaliteit en rechtshandhaving 2014. Ontwikkelingen en samenhangen. Den Haag: Boom Juridische uitgevers, 37-44.

Verstege, D. \& Wingerden, S. van (2009). Ook de mondelinge motivering van de straftoemetingsbeslissing laat te wensen over. Proces, 88(1), 36-46.

Wartna, B.S.J., Blom, M. \& Tollenaar, N. (2011). De WODC-Recidivemonitor (Memorandum 2011-3). Den Haag: WODC.

Werff, C. van der (1978). Eis en vonnis bij rijden onder invloed. Den Haag: WODC.

Werff, C. van der \& Zee-Nefkens, A.A. van der (1978). Strafrechtelijke vervolging en bestraffing van Nederlanders en buitenlanders. Den Haag: WODC.

Wingerden, S. van \& Nieuwbeerta, P. (2010). Straftoemeting bij moordenaars. De invloed van dader-, slachtoffer- en delictkenmerken. Straftoemetingsbulletin, 33(1), 11-21.

Zoomer, O. (1981). De strafvordering en straftoemeting in gevallen van zware criminaliteit. Een overzicht van de jaren 1973-1976 en een analyse van de beslissingen van officieren van justitie. Den Haag: Staatsuitgeverij. 